\title{
Bibliography of Finnish Population Research $1979-1980$
}

The biblography covers the literature on population research published in Finland during 1979-1980. Included are independent publications, articles in periodicals and statisties published in Finland as well as publications on Finnish population questions published abroad. In general the bibliography excludes nonscientific articles in newspapers and weeklies as well as unpublished reports and academic theses. Also not included are studies presented at proceedings of conferences held in Finland if they were written abroad and treated subjects outside Finland. Coverage is less complete in peripheral fields.

In principle the main divisions appearing in the Population Index have been used with added subdivisions better suiting Finnish circumstances. Studies covering several fields of demography, which should rightly be listed in two or more divisions are included in only one division, i.e. in the division representing the primary field, on which the report is centered.

Lists of literature on population research have been published in Yearbooks II-IV of the Finnish Population and Family Welfare Federation and since 1960 in the Yearbook of Population Research, at first every fourth year and now every second year.

\section{A. GENERAL POPULATION STUDIES AND THEOIY}

Haavio-Mannila, Elina and Kari, Kyllikki. Demographic background of changes in the life patterns of families in the Nordic countries. University of Helsinki/Dept. of Sociology, Working papers No. $11,1979,78 \mathrm{p}$.
Herva, Aslak. Characteristics of Finnish population dynamics in 1977. Scandinavian Population Studies 5, pp. 309317. The Scandinavian Demographic Society, Oslo 1979.

Kulokari, Hannu. Ennustemallin kritiikkiä (Criticism on the population projection) In "Demografian jatkokoulutusseminaari 1978». Demographic Society of Finland, publ. no. 5, pp. 29-33. Helsinki 1979.

Rymalov, V. Kapitalististen ja kehitysmaiden väestö ja työvoimavarat (Population and labor resources in capitalistic and developing countries). Sosialismin teoria ja käytäntö 1979: 17, pp. 25-34.

Salo, Mikko. Lapsi ja tutkimus väestötieteen näkökulmasta (Children and research from a demographic viewpoint). Lapset ja yhteiskunta, vol. 12, 1979, pp. $561-564$.

\section{B. REGIONAL POPULATION STUDIES}

Alanen, Antti and Haapala, Pertti. Työväenluokan synty Tampereella. Työväenluokan taloudellinen ja demografinen muodostuminen vuosina $1830-1905$. Työväenluokan asema ja tietoisuus vuoden 1905 suurlakkoon asti (Birth of the working class in the city of Tampere. The economic and demographic formation of the working class in $1830-1905$. The status and consciousness of the working class till the general strike in 1905). University of Tampere/Dept. of Sociology and Social Psychology, Report No. 37/1979. 262 p. + Annex.

Aura, Teuvo. Helsingin asukasmäärän ja väestörakenteen muutokset ja niiden vaikutukset (Population rates and changes of the population structure in Helsinki and their impacts). The Sta- 
tistical Centre of the City of Helsinki/ Neljännesvuosikatsaus 1979: 2, pp. 5-22.

Kemppainen, Eeva-Kaisa. Ulkokuntalaisselvitys (Study of population resident in Helsinki but domicited elsewhere). Statistical centre of the City of Helsinki. Studies and report series 1979: 7.

Kuusilinna, Pirjo. Väkiluku ja asunnot keskeisellä suuralueella (Population and dwellings in a central area). Tilastollisia tiedonantoja Tampereelta 1979: $1-2$, pp. 3-14. Tampere 1979.

Markkanen, Erkki. Maaseutuväestön varallisuusolot ja luottosuhteet SisäSuomessa elinkeino-elämän murroskaudella v. 1905-1914 (The economic status and credit relationships of the rural population in inner-Finland in the crisis period of economic life 1905-1914). Studia Historica Jyväskyläensia 14. Jyväskylä.

Moilanen, Raisa-Liisa. Somerovaaran asutusalueen asuttaminen, väestön kehitys ja osittainen autioituminen (The settling of Somerovaara, its population development and partial desolation). Siirtolaisuus - Migration 1979: 1, pp. 17-28.

Piironen, Pekka. Viljelijöiden tulorakennemuutos ja monitoimisuus PohjoisSavossa (The changes of income structure and manifold activity in Northern Savo). Reports and articles No. 12 of Pellervo-seuran markkinatutkimuslaitos. 1979.

Turpeinen, Oiva. Lahden alue ja väestö (The region of Lahti and its population). In "Lahti's history». Hämeenlinna 1980, pp. $13-145$.

\section{SPATIAL DISTRIBUTION}

Allardt, E, - Miemois, K-J. Roots both in the centre and the periphery: The Swedish speaking population in Finland. Research Reports No. 24 of the Research Group for Comparative Sociology, University of Helsinki 1979, 84 p.

Vartiainen, Pertti. Suomen alueellisesta väestönkehityksestä 1970-luvulla (Regional population development in Finland in the 1970's). Terra 1979: 3, pp. 147160.

Rannikko, Pertti. Suomen suurimpien kaupunkien väestönkasvun hidastuminen (The diminuation of population growth in the largest Finnish cities). The University of Jyväskylä, Karjala Research Institute No. 43, 1980, 213 p.

\section{TRENDS IN POPULATION SIZE}

Fougstedt, Gunnar. Aktuella befolkningstrender sedda i globalt perspektiv (Current population trends approached from a global perspective). Societas Scientiarum Fennica, Yearbook LVIII (1980) B, No. 2, 26 p.

Hulkko, Jouko. Population development and population policy in Finland. Yearbook of Population Research in Finland, XVII, pp. 15-31, The Population Research Institute, 17, 1979, pp. 15-31. Helsinki 1979.

Kemppainen, Eeva-Kaisa. Den svenskspråkiga befolkningens utveckling i Helsingfors - befolkningen 1.1.1972-1979 samt prognoser för 1.1.1981 och 1.1. 1986 (The development of the Swedish speaking population in Helsinki - population 1.1.1972-1979 and preliminary data for 1.1.1981 and 1.1.1986). The Statistical Centre of the City of Helsinki. Statistik 1980: A: 2, 13 p.

Kortteinen, Timo. Palkkatyöväestön rakenteesta Suomessa v. 1850-1913 (On the structure of wage earners in Finland 1850-1913). Communications - Institute of Economic and Social History, University of Helsinki, No. 1980.

Lallukka, Seppo. Neuvostoliiton vuoden 1979 väestönlaskenta (The 1979 census in the USSR). Terra, vol. 91, 3, 1979.

Mella, Ilkka. Katsaus maapallon väestönkehitykseen (World population development). In $\gg$ Demografian seminaarit 1979». Demographic Society of Finland publ. 6 , pp. 7-16. Helsinki 1980.

Mella, Ilkka. Lasten määrän kehitys Suomessa vuosina 1980-2000 (Number of children in Finland in 1980-2000). In Demografian seminaarit 1979». De- 
mographic Society of Finland, publ. 6, pp. 80-86. Helsinki 1980.

Nieminen, Mauri. Väestönkehitys Tansaniassa (Population development in Tanzania). In »Demografian seminaarit 1979». Demographic Society of Finland, publ. 6, pp. 33-39. Helsinki 1980.

National Insurance Institution. Väestöennuste. Eläkkeensaajien lukumääriä koskevat ennusteet 1980-2050 (Population forecast. Preliminary data on pensioners in 1980-2050). 1980, 43 p. + app.

Pitkänen, Kari. Finlands folkmängd år 1949 (Finland's population in 1949). Finnish Historical Review 1979 (1): 22-40.

Pitkänen, Kari. Väestörakenteen muuttuminen ja väestönkehitys (Changes in the population structure and population trends). Finland's economic history I, pp. 367-385. Helsinki 1980.

Salo, Mikko. 1980-luvun väestökehityksen näkymät Suomessa (Population perspectives in the 1980's in Finland). Sirtolaisuus - Migration 1980: 2, pp. 16-23.

Valkonen, Tapani. Väkiluvun ja ikärakenteen kehitys (Population development and age structure). In Suomalaiset, Juva 1980 , pp. $181-221$.

Wiman, Ronald. Syntyvyyden näkymät ja ennustajan näkökulmat (Future prospects of fertility and the predictor's aspects). In Demografian jatkokoulutusseminaari 1978 ». Demographic Society of Finland, publ. 5, pp. 34-51. Helsinki 1979.

\section{E. MORTALITY}

Kolari, Risto. On cohort mortality in Finland. Yearbook of Population Research in Finland, XVIII, pp. 35-47. The Population Research Institute. Helsinki 1980.

Kolari, Risto. Kuolleisuus. Kohorttikuolleisuus Suomessa v:sta 1851 lähtien (Mortality. Cohort Mortality in Finland since 1851). Statistical Office, Reports No. 57 , Helsinki 1980,97 p.

Koskenvuo, M., Kaprio, J. Väestön kuolleisuuden vaihtelu Suomessa lää- neittäin, siviilisäädyittäin ja sosiaaliryhmittäin (Changes in mortality among the active population in Finland by province, civil status and social class). Soc. med. review 1980: 17, pp. $130-138$.

Koskenvuo, M. - Sarna, J. - Kaprio, J.-Lönnqvist, J. Cause-specific mortality by marital status and social class in Finland during 1969-1971. Soc. Sci. \& Med. 13 A: 1979, pp. 691-697.

Koskenvuo, M. - Kaprio, J. - Kesäniemi, A. - Sarna, S. Differences in mortality from ischemic heart disease by marital status and social class. J. Chron. Dis. 33: 1980, pp. 95-106.

Notkola, Veijo. Alueelliset kuolleisuuserot Suomessa 1950-75 (Regional differences in mortality in Finland in 195075). The University of Helsinki, Dept. of Sociology, Reports No. 218, 1980, 188 p.

Pitkänen, Kari. The changing features of mortality in Finland in the 18th and 19 th centuries. Seandinavian Population Studies 5, pp. 74-82. The Scandinavian Demographic Society. Oslo 1979.

Poikolainen, Kari. Dödligheten i alkoholförgiftning i Danmark, Finland, Norge och Sverige (Mortality from alcoholism in Denmark, Finland, Norway and Sweden). Nordisk Medicin 94: 1979.

Poikolainen, Kari. Dödsfall i alkoholförgiftning i fyra nordiska länder. I Registrerad dödlighet. II Orsaker till skillnaderna i dödlighet. Mortality from alcoholism in four Nordic countries. I Registered mortality. II Causes. Alkoholipolitiikka 42: 1979.

Poikolainen, Kari. From inebriation to incremation - Finnish drinking habits and mortality. Psychiatria Fennica 1978. Helsinki 1979.

Poikolainen, Kari. Paraneeko Euroopan sairas mies? (Will the sick man of Europe recover?). Duodecim 95: 1979.

Poikolainen, Kari. Veränderungen der Mortalität in den Entwicklungsländern. In "Demoökonomische Probleme der Entwicklungsländern» (ed. Parviz Khalatbari), s. 163-180. Akademie-Verlag, Berlin 1979.

Sauli, Hannele. The socio-economic aspect of occupational mortality in Fin- 
land. In »Scandinavian Population Studies 5n, The Scandinavian Demographic Society, pp. 131-142. Oslo 1979.

Sauli, Hannele. Kuolleisuus. Ammatti ja kuolleisuus 1971-75 (Mortality and occupation in 1971-75). Statistical Office, Reports No. 54. Helsinki 1979, 158 p.

Turpeinen, Oiva. Die Sterblichkeit an Pocken, Masern und Keuchhusten in Finland. In »Mensch und Gesundhert in der Geschichte" (Hrsgl. A. E. Imhof). Abhandlungen zur Geschichte der Medizin und der Naturwissenschaften, Heft 39.

Turpeinen, Oiva. Fertility and mortality in Finland since 1750. Population Studies, pp. 101-114. London 1979.

Turpeinen, Oiva. Infant mortality in Finland in 1749-1865. Scandinavian Economic History Review 1979, 27 (1), pp. 1-21. Jyväskylä 1979 .

Turpeinen, Oiva. Monthly mortality in Finland in 1751-1806. Yearbook of Population Research in Finland, XVII, pp. 59-73. The Population Research Institute. Helsinki 1979.

Turpeinen, Oiva. Kuolleisuus PäijätHämeessä Suomen sodan vuosina 18081809 (Mortality in Päijät-Häme during the war-years 1808-1809). Yearbook of the Päijät-Häme Research Society 1980, pp. 117-124. Lahti 1980.

Valkonen, Tapani. Comment on occupational mortality. Scandinavian Population Studies 5, pp. 143-150. The Scandinavian Demographic Society. Oslo 1979.

Valkonen, Tapani. Discussion statement on socioeconomic determinants of mortality in developed countries. Proceedings of the meeting on socioeconomic determinants and consequences of mortality held in Mexico City, June 1979, N. Y. 1980 , pp. $373-375$.

Valkonen, Tapani. Kuolleisuus (Mortality). In Otavan Suuri Ensyklopedia 5, pp. 3346-3348. Keuruu 1978.

Valkonen, Tapani - Niemi, MarjaLiisa. Keski-ikäisen väestön kuolleisuus Suomessa vuoden 1950 jälkeen (Mortality of the middle-aged population in Finland since 1950). Sosiaalilääketieteellinen Aikakauslehti 1978: 5.
Valkonen, Tapani - Niemi, MarjaLiisa. Miesten kuolleisuuden kehitys läänin ja kuolemansyyn mukaan Suomessa vuosina 1961-75 (Mortality development among men in Finland in $1961-75$ by cause of death and province). Dept. of Sociology, University of Helsinki, Working papers $12,1980,71 \mathrm{p}$.

\section{F. FERTILITY AND NATURAL INCREASE}

Finnäs, Fjalar - Hoem, Jan M. Starting age and subsequent birth intervals in cohabitational unions in current Danish cohorts, 1975. Demography 17: 3, pp. 275-295.

Lindgren, Jarl. Nuptiality and marital fertility during the first phase of industrialization in Finland. Yearbook of Population Research in Finland, XVIII, pp. 80-95. The Population Research Institute. Helsinki 1980.

Mattila, Rauno E. Hedelmöitysten, kaksosfrekvenssin sekä sukupuolten lukusuhteen vaihtelu Suomessa 1751-1969 (Variations in conceptions, twin frequency and sex ratio in Finland in 1751-1969). Helsinki 1980, 104 p. (With English Summary).

Riihinen, Olavi - Pulkkinen, Aimo Ritamies, Marketta. The realization of family planning in Finland with particular reference to the development in the 1970s. Yearbook of Population Research in Finland, XVII, pp. 32-44. The Population Research Institute. Helsinki 1979.

Riihinen, Olavi-Pulkkinen, AimoRitamies, Marketta. Suomalaisen perheen lapsiluku (Number of children in the Finnish family). The Population Research Institute, Ser. D: 7, 1980, Helsinki, 154 p. + Annex.

Riihinen, Olavi - Pulkkinen, Aimo Ritamies, Marketta. Fertility and welfare-categories in Finland. A need-theory approach to the size of family. Reports of the University of Helsinki, Dept. of Social Policy No. $3 / 1979,19$ p. Published also in The Scandinavian Population 
Studies 5, pp. 226-244. The Scandinavian Demographic Society. Oslo 1979.

Ritamies, Marketta. Fertility and legal abortions. Yearbook of Population Research in Finland, XVII, pp. 45-52. The Population Research Institute. Helsinki 1979.

Salo, Mikko. On control over fertility regulation. Social Praxis, Vol. 7: 3-4. Haag 1980.

Turpeinen, Oiva. Fertility and mortality in Finland since 1750. Population Studies vol. 33: 1, 1979.

\section{G. MARRIAGE, DIVORCE AND THE FAMILY}

Haavio-Mannila, Elina - Kari, Kyllik$k i$. Changes in the life patterns of families in the Nordic countries. Yearbook of Population Research in Finland, XVIII, pp. 7-34. The Population Research Institute. Helsinki 1980.

Kansainvälisen lapsen vuoden 1979 Suomen komitea (Finnish Committee for the International Year of the Child 1979). Report of the Committee 1980: 23, Helsinki 1980, $218 \mathrm{p}$.

Koskelo, Pauliine. Avioerot ja nilihin vaikuttaneet tekijät vuosina $1930-1977$ (Divorces and factors affecting them, 1930-1977). Oikeusministeriön lainvalmisteluosaston julk. 1979: 8. Helsinlki 1979, $96 \mathrm{p}$.

Lindgren, Jarl. A New Phenomenon: Cohabitation outside marriage. Yearbook of Population Research Institute, XVII, pp. 53-57. The Population Research Institute. Helsinki 1979.

Saarinen, Aino. Perhe ja sukupolvittaisen uusintamisen ristiriidat kapitalismissa (The family and the conflicts of reproduction in capitalism). University of Tampere, Reports No. 11/79, 44 p.

Salo, Mikko. On the economics of family formation. A microsimulattion. Journal of Interdisciplinary modeling and simulation. July 1979 . pp. 263-276.

Suominen, Leena. Work and families with children. Yearbook of Population Research in Finland, XVII, pp. 74-83.
The Population Research Institute. Helsinki 1979.

Suominen, Leena. Lapsiperhe Suomessa (The family with children in Finland). Kolmikantasarja No. 7, The Finnish Population and Family Welfare Federation, 1979, $158 \mathrm{p}$.

\section{H. MIGRATION}

\section{International Migration}

Engman, Max. Migrationen från Finland till Ryssland - forskningsläge och huvuddrag (with English Summary) (Migration from Finland to Russia - research situation and main features). Siirtolaisuus - Migration 1980: 3, pp. 10-18.

Koivukangas, Olavi (Ed.). Utvandringen från Finland till Sverige genom tiderna. Siirtolaisuus Suomesta Ruotsiin kautta aikojen (Outmigration from Finland to Sweden through the ages). Turku 1980, $100 \mathrm{p}$.

Lindström, Kai - Söderling, Ismo. Om problemen för de unga som flyttat från landsbygden till städerna. (About problems of the young migrants from the countryside to towns). Siirtolaisuus Migration 1979: 3, pp. 14-17.

Majava, Altti. The Scandinavian countries: Denmark, Finland, Norway, Sweden. In "The politics of migration studies. The first world in the 1970s" (Ed. Daniel Kubat, Ursula Mehrländer and Ernst Gemacher, pp. 163-191. Center to Migration Studies, New York 1979. Majava, Altti. Sopemi. Migrations from and to Finland in 1979. Ministry of Labor, Helsinki 1980, $48 \mathrm{p}$.

Majava, Altti. Siirtolaiset - neljäs maailma (Migrants - the fourth world). In »Demografian seminarit 1979». Demographic Society of Finland, publ, 6, pp. 63-72. Helsinki 1980.

Rikkinen, K. Migration and settlement: 2 Finland. International Institute for Applied System Analysis. RR-799, Nov. 1979.

Sandlund, Tom. Den finlandssvenska emigrationen (Emigration of the Swedish 
speaking Finns). Skärgård 1979: 1, pp. $26-28$.

Ruotsiin muuton ongelmat (Problems of migration to Sweden). Migration Studies A 7, 1979, Siirtolaisinstituutti (Migration Institute) $247 \mathrm{p}$.

Svenska emigrationskommitténs betänkande. Suomenruotsalaisen siirtolaisuuskomitean mietintö 1980: 24 (The Committee Report of the Swedish Emigration Committee 1980: 24). Helsinki 1980, 109 p.

Tessieri, Enrique. The second-generation Finns of Argentina: a process towards Argentinization. Sirtolaisuus Migration 1979: 2, pp. 8-13.

Uola, Mikko. Suomalaismasinisteja Kongossa (Finnish machinists in the Congo). Siirtolaisuus - Migration 1979: 3 , pp. $1-13$.

Valkonen, Tapani - Kulokari, Hannu. Siirtolaisuuden vaikutukset väestönkehitykseen (The impact of emigration in population development). Siirtolaisuustutkimuksia A. 7.

Wiman, Ronald. Muuttoliike (Migration). Otavan suuri ensyklopedia, part VI, Helsinki 1979, pp. 4503-4.

Virtanen, Keijo. Settlement or return: Finnish emigrants $(1860-1930)$ in the international overseas return migration movement. Forssa 1979, Migration Institute, Migration Studies C: 5 . 274 p.

\section{Internal Migration}

Helsingin kaupungin seutukaavaliitto (Regional planning association of the City of Helsinki). Helsingin sisäisen muuttolilikkeen pilirteitä (Features of the internal migration in Helsinki). Yleiskaavaosaston julkaisu YA: 2/1979.

Hietala, Kari. Muuttoliike ja epätäydelliset työvoimamarkkinat (Migration and an incomplete labor market). Migration Studies 16, 1980, 208 p.

Hietala, Kari. De direkta investeringarnas sysselsättnings- och migrationsverkan (The effect of direct investments on employment and migration). The Helsinki School of Economics, Report B-45. Helsinki 1980, 104 p.
Hietala, Kari. Maassamuutto teknologisen kehityksen aiheuttamaan rakennemuutokseen sopeutuvana tekijänä (Migration as an adjusting factor of structural changes caused by technological development). In "Demografian jatkokoulutus seminaari 1978». Demographic Society of Finland, publ. no 4, 1979 pp. 62104. Helsinki 1979.

Mäkelä, Anneli. Hattulan kihlakunnan ja Porvoon läänin autioituminen myöhäiskeskiajalla ja uuden ajan alussa (Desolation of the Hattula district and Porvoo province in the late Middle Ages and in early modern times). University of Helsinki, Doctoral thesis 1979, $276 \mathrm{p}$.

Nieminen, Mauri. Suomen muuttoliike tilastojen valossa (Finland's migration by statistics). Siirtolaisuus - Migration 1979: 1, pp. 1-9.

Ojala, Veijo. Maassamuuton merkitys ja ennustettavuus (The impact of internal migration and the possibilities to predict at). In $\gg$ Demografian jatkokoulutusseminaari 1978», pp. 48-53. The Demographic Society of Finland, publ. 5. Helsinki 1979.

Pöntinen, Seppo. On the social mobility of women in the Scandinavian countries. Commentationes Scientiarum Socialium 14/1980. Societas Scientiarum Fennica. Helsinki, $50 \mathrm{p}$.

Sarin, Mirja. Helsingin muuttoliikkeen piirteitä, syitä ja näkymiä (Causes, features and perspectives for migration in Helsinki). The Statistical Center of the City of Helsinki, 1979: 3, pp. 5-24.

Tampereen kaupungin tilastotoimisto (Statistical Office of the City of Tampere, 1979). Suunnitelmia Tampereen muuttolikkeen syiden tutkimiseksi (Plans to investigation the reasons for migration in Tampere). Tilastollisia tiedonantoja Tampereelta 1979: 4, pp. 107-122.

Söderling, Ismo. Maassamuuttotutkimuksen teoreettisista lähtökohdista (On the theoretical basis of migration research). Siirtolaisuus - Migration 1980: 2 , pp. $24-32$.

Vartiainen, Perttu. Muuttoliike alueellisen kehityksen mekanismina Pohjois- 
Karjalassa 1960-luvulla ja 1970-luvun alkupuolella (Migration as a mechanism affecting the regional development of the province of Pohjois-Karjala in the 1960 s and the beginning of the 1970s). Joensuun korkeakoulu, Historian, maantieteen ja muiden aluetieteiden osaston julk. 12. Joensuu 1979, 128 p.

Vartiainen, Perttu. Pohjois-Karjalan uusteollistumisen vaikutukset työvoiman liikkuvuuteen spatiaalisessa kontekstissa (The effect of the new industrialization in the province of Pohjois-Karjala on the migration of the labor force in the spatial context). Joensuun korkeakoulu, Historian, maantieteen ja muiden aluetieteiden osaston julk. n:o 13, Joensuu 1979, 53 p.

Jutikkala, Eino. Kaupungin väestö (The population of the city). In Tampereen kaupungin historia 3, 1905-1945 (History of Tampere 3, 1905-1945), pp. 5-35. Tampere 1979.

Jutikkala, Eino. Asutus ja väestö (Settlement and populabion). In Suomen taloushistoria I, pp. 149-170. Helsinki 1980 .

Kaukiainen, Yrjö. Social structure and demographic development in a Southern Finnish parish (Lohja), 1810-1850. Annales academiae scientiarum fennicae, ser. B: 204. Helsinki 1979, 47 p.

Turpeinen, Oiva. Päijät-Hämeen väestönkehitys 1505-1979 (Population development in Päijät-Häme). Yearbook of Päijät-Häme 1980, pp. 6-19. Lahti 1980.

Pitkänen, Kari. Finlands folkmängd år 1749 (The population of Finland in 1974) Historisk Tidskrift för Finland 1979: 1 .

\section{J. CHARACTERISTICS}

Aromaa, Arpo. Viljelijäväestön terveydentila tilastotiedoin ja väestötutkimuksin arvioituna (The state of health of farmers estimated from statistical data and population studies). Social Insurance Institution E: 105, 1979.
Karjalainen, P. - Marin, R. Erityisryhmätutkimus: Osa: Saamelaiset (Special group report: Lapps). Ministry of Social Affairs and Health, 10, 1979, 73 p.

Karjalainen, P. - Marin, R. Erityisryhmätutkimus: Osa: Mustalaiset (Special group report: Gipsies). Ministry of Social Affains and Health, 9, 1979, 81 p.

The regional planning association of Helsinki, Uusien asuntojen väestön ikärakenne (The age structure in new dwellings). YA: 7, 1979.

Huuhtanen, Pekka. On the psychological effects of migration. Acta Psychologica Fennica VI, 1979.

\section{K. DEMOGRAPHIC AND ECONOMIC INTERRELATIONS}

Bingham, T. R. G. Väestömuutokset ja taloudellinen kasvu (Population change and economic growth). Unitas 4. 1980, pp. 181-186.

Haavio-Mannila, Elina. Sukupuolten elintasoerot Ruotsin sirtolaisten keskuudessa (Differences in standard of living among migrants in Sweden). Sociology 1: 1979 , pp. 31-41.

Kandolin, T. - Uusitalo, H. Scandinavian men and women: a welfare comparison. Research Group for Comparative Sociology, University of Helsinki. Research Report 28, 1980, 70 p.

Lindgren, Jarl. Aging - a demographic and economic problem. Yearbook of Population Research in Finland, XVII, pp. 84-90. The Population Research Institute, Helsinki 1980.

Lindgren, Jarl. Ikärakenteen vanheneminen (The change toward an older age structure - a demographic or an economic problem). In "Demiografian jatkokoulutusseminaari 1978». Finnish Demographic Society publ. 5, pp. 5461. Helsinki 1979.

Salo, Mikko. Taantuva talous, kasvava väestö ja sosiaalipolitiikka - tapaus Mauritius (Stagnating economy, growing populations and social policy the case of Mauritius). Sosiaalipolitiikka 1979. 


\section{OTHER INTERRELATIONS}

Komiteanmietintö 1980: 7. Työpaikkaja väestösuunnitetoimikunnan mietintö (Report of the Committee on Employment and Population Forecasts). Helsinki 1980, 77 p. + annex.

Wiman, Ronald, Ikärakenteen muutos maastamuuton taustatekijänä (Changes in age structure as a background factor for emigration). In Talous ja yhteiskunta (Economy and Society). (Ed. HaranneSeppälä-Siurala) The Helsinki School of Economics, mimeograph 145, 1980.

\section{POLICIES}

Hatunen, Hellevi. Perhepoliittinen keskustelu eduskunnassa 25-27.3.1980, 4. 7. 1980 (Discussion on family policy in the Parliament). The Finnish Population and Family Welfare Federation, $48 \mathrm{p}$.

Heikkilä, M. - Karjalainen, T. - Lihr, S. - Niinivaara, R. Perhekustannusten tasausjärjestelmä Suomessa (The system of equalization of family expenses in Finland). Administration of Social Welfare 4, 1979, 70 p. + annex.

Ilander, Kaija. Kansainvälisen työjärjestön, ILO:n väestö ja työllisyysprojekti Aasiassa (The population and employment project of the International Labour Organisation, ILO, in Asia). In "Demografian seminaarit 1979». Demographic Society of Finland, publ. 6, pp. 28-32. Helsinki 1980.

Kasanen, Viljo - Kuikka, Ritva Keskimäki, Kaija - Rahunen, Aila. Alle kouluikäisten lasten kotihoidon tuki Espoossa. 14. 1. 1977 (Home care support of children under school age in Espoo). Social bureau of Espoo 1979. $13 \mathrm{p}+$ annex.

Lehto, Markku. Tarvitaan kokonaan uusia perhepoliittisia toimenpiteitä (Entirely new family policy measures are necessary). Sosiaalinen aikakauskirja 4, 1980, pp. $19-26$.

Lallukka, Seppo. Sosialistinen perhe ja väestöpolitilkka. Piirteitä Tsekkoslovakian, Unkarin ja Neuvostoliiton jär- jestelmistä (The socialist family and family policy. Features of the systems of Czechoslovakia, Hungary and the USSR). In Demografian seminaarit 1979». Demographic Society of Finland, publ. 6, pp. 40-57. Helsinki 1980 .

Lindgren, Jarl. Mitä lapsi maksaa? (Cost of raising a child?). Council of Consumption 1, 1980, Helsinki, 38 p.

Lindgren, Jarl. Ranska, perhepolitiikan esikuva (France, the model of family policy) In $»$ Demografian seminaarit 1979». Demographic Society of Finland, publ. 6, pp. 58-62. Helsinki 1980.

Mannerheimin Lastensuojelun Keskusliitto. Lapsen perusturva 1980, ML:n Lapsipoliittinen ohjelma (Basic security of the child 1980, Family policy program), Helsinki 1980, $132 \mathrm{p}$.

Marjanen, Matti - Lähteinen, Martti. Palvelut ja toimeentuloturva perhepolitiikan välineinä (Services and subsistance security, means of family policy). Sosiaalinen aikakauskirja 4, 1980, pp. $27-34$.

Salo, Mikko. Mahdollisuuksia vaikuttaa yhteiskuntapoliittisin toimenpitein perheellistymiseen ja syntyvyyteen (Possibilities to influence on nuptiality and fertility by means of social policy). Sosiologia, vol. 17,1980 , pp. $46-56$.

Suominen, Risto. Perhepoliittiset etuudet Pohjoismaissa (Family policy services in the Nordic countries). Sosiaalinen aikakauskirja 4, 1980, pp. $40-46$.

Suominen, Risto - Tuisku, Terho. Sosiaalisia erikoistutkimuksia: Lapsiperheen tulo- ja kulutusrakenne vuonna 1976 (Income and consumption structure of families with children in 1976). Official Statistics of Finland XXXII: 59, Helsinki 1979, $125 \mathrm{p}$.

Suviranta, Annikki. Kokemuksia lasten kotihoidon tuen kokeilusta (Experiences of the home care support experiment for children). Sosiaalinen aikakauskirja 4, 1980, pp. 35-39.

Tamasy, Josef. Unkarin väestö- ja perhepolitilkkaa (Population and family policy in Hungaria). Kanava 1979: 5, pp. 271-277.

Valtioneuvoston perhepoliittinen se- 
lonteko 25. 3. 1980 (Family policy report of the Council of State 25.3.1980). Helsinki, 1980, $19 \mathrm{p}$.

Visuri, Elina. Maailman väestöpoliittinen toimintaohjelma ja sen seuranta (World population policy program and its follow-up). In "Demografian seminaarit 1979». Demographic Society of Finland, publ. 6, pp. 22-27. Helsinki 1980.

\section{N. METHODS OF RESEARCH AND ANALYSIS}

Finnäs, Fjalar. A method to estimate demographic intensities via cumulative incidence rates. Theor. Pop. Biol. 17: 3, 1980 , pp. $365-379$.

Laaksonen, Seppo. On sensitivity in population forecasts. Yearbook of Population Research in Finland, XVIII, pp. 96-101, The Population Research Institute, Helsinki 1980.

Markelin, Pasi. Population censuses in Finland. Some topical methodological problems in official statistics. Central Statistical Office of Finland \& Council for Mutual Economic Assistance, Secretariat. Helsinki - Moscow 1980, pp. 90-104 (Available also in Russian).

Nieminen, Mauri. Statistical use of registers in Finland. The Scandinavian Population Studies 5, pp. $164-175$. The Scandinavian Demographic Society. Oslo 1979.

Pitkänen, Kari. Registering people in a changing society - the case of Finland. Yearbook of Population Research in Finland, XVIII, pp. 60-79. The Population Research Institute, Helsinki 1980.

Salo, Mikko A. Difficulties in assessing pro-natalist population policy programs. Yearbook of Population Research in Finland, XVIII, pp. 48-59. The Population Research Institute, Helsinki 1980.

Salo, Mikko A. Pretesting input data for computer simulation models. Scandinavian Population Studies 5, pp. 292-
302. The Scandinavian Demographic Society. Oslo 1979.

The Statistical Central of the City of Helsinki. Väestötilastojen kehittäminen (Developing population statistics) $7 / 1979$.

Tuomikoski, Hannu. Regressio- ja AIDanalyysien käyttö alueellisissa selitysmalleissa (Use of regression and AIDanalysis in regional explanation models). Social Insurance Institution M: 35, 1979, Helsinki 59 p.

\section{O. ORGANIZATION AND ADMINISTRATION}

Helsingin seutukaavaliitto (Regional Planning Association of Helsinki). Helsingin seudun väestö- ja työpaikkasuunnitteet sekä kerrosalaennusteet (Population and employment planning and forecast for room space). Helsinki 1980.

The Central Statistical Office of Finland, Väestö- ja asuntolaskenta 1980. Tietojen käyttöönsaattaminen, systeemisuunnitelma. Osa I. (Population and dwelling census 1980. Disposition of data, system planning. Part I). Helsinki 1980. $168 \mathrm{p}$.

The Central Statistical Office of Finland, Väestö- ja asuntolaskenta 1980. Tietojen käyttöönsaattaminen, taulumallit. Osa II. (Population and dwelling census 1980. Disposition of data, table models. Part II). Helsinki 1980, 213 p.

Tuomisaari, T., Taloudellis-demografinen väestö- ja työpaikkaennustejärjestelmä seutusuunnittelussa (An economicdemographic population and employment forecast system in regional planning). 1979.

Vantaan kuntasuunnittelutoimisto (Communal Planning Office of Vantaa). Vantaan väestöennustemalli 1979 (Population forecast model 1979 of Vantaa). Vantaa 1979.

Vantaan kuntasuunnittelutoimisto (Communal Planning Office of Vantaa). Vantaan väestösuunnite 1979-88 (Population project $1979-88$ of Vantaa). Vantaa 1979. 


\section{P. PROFESSIONAL MEETINGS AND CONFERENCES}

Demographic Society of Finland. Demografian jatkokoulutusseminaari 1978. Lammilla 22-23.11.1987 pidetyt esitelmät (Extension training seminar 1978. Proceedings held in Lammi November $22-23,1978)$. Publication of the Demographic Society of Finland no. 5, Helsinki 1979.

Demographic Society of Finland. Demografian seminaarit 1979. Jatkokoulutusseminaarissa Lammilla 22-23. 11. 1979 ja kansainvälisen lapsen vuoden seminaarissa Helsingissä 23.10.1979 pidetyt esitelmät (Demographic seminars 1979. Proceedings held at the extension training seminar in Lammi November 22-23, 1979 and at the International Child Year Seminar October 23, 1979 in Helsinki). Publications of the Demographic Society of Finland no. 6, Helsinki 1980.

Munther, Arja (ed.). Ruotsiin muuton ongelmat. Ruotsin siirtolaisuuden seminaari 4.-5. 5. 1978. Esitelmät ja keskustelut (Problems of emigration to Sweden. Seminar on emigrattion to Sweden, May $4-5$, 1978. Reports and discussions). Vaasa 1979.

Pohjois-Karjalan Historiallinen Yhdistys (The North Carelian Historical Society), Itä-Suomen asutus- ja väestöhistoriaa (Eastern Finland's building and population history). Papers presented at seminar in Joensuu June 27-28, 1978. Joensuu 1980, 82 p.

The Scandinavian Demographic Society, The Fifth Scandinavian Demographic Symposium 13-16 June 1979 at Hurdalssjøen, Norway. Scandinavian Population Studies 5, Oslo 1979. 324 p.

UN Population Commission. Report of the Finnish delegation on the 20th session of the UN Population Commission January 29 - February 9, 1979.

\section{Q. BIBLIOGRAPHIES}

Bibliography of Finnish Population Research 1977-1978. Yearbook of Popu- lation Research in Finland, XVII, pp. 98-108. The Population Research Institute, Helsinki 1979.

Järvenpää, Iris, Helsingin kaupungin yhiteiskuntatutkimus 1979-1980 (Societal studies $1979-1980$ of the City of Helsinki). Helsinki 1980, 81 p.

\section{R. OFFICIAL STATISTICAL PUBLICATIONS}

Causes of death in Finland 1975. Official Statistics of Finland VI B: 131. Helsinki 1979,116 p. $-1976,1980$, SVT VI B: $132,112 \mathrm{p}$.

Ikä ja ammattitilastot 1977 (Age and occupation 1977). Kansaneläkelaitoksen tilastollisia vuosikatsauksia T 3:6 A (Review of the Social Insurance Institution T 3:6 A). Helsinki 1980, 119 p.

Kolari, Risto, Kuolleisuus- ja eloonjäämistauluja kuolemansyiden mukaan 1971-1975 (Life tables by causes of death 1971-75). The Central Statistical Office, VA 1980: 7, 42 p.

Mortality 1971-1975. Life tables 1971-1975. Official Statistics of Finland VI A: 142, 1980, 61 p.

Statistical Yearbook of Finland 1978. Helsinki 1979. 528 p. - 1979, 1980, 547 p.

Tampereen kaupungin tilastollinen vuosikirja 1978/79 (Statistical Yearbook of the City of Tampere 1978/79). Tampere $1980,236 \mathrm{p}$.

Turun kaupungin tilastollinen vuoijkirja 1978/79 (Statistical Yearbook of the City of Turku 1978/79). Turku Office of Statistics 1980,249 p.

Population by industry: Population by industry and commune in 1880-1975. Central Statistical Office of Finland, Statistical Information No. 63. Helsinki 1979, $370 \mathrm{p}$.

Population 1978. Central Statistical Office of Finland VI A: 143, Vol. I: Structure of population and vital statistics. Whole country and its provinces. Helsinki 1980, 83 p. Vol. II: Structure of population and vital statisties by commune. Helsinki 1980, 127 p. Vol. III: In- 
ternal Migration by Commune, Helsinki 1980, $154 \mathrm{p}$.

Population projections 1978-2020: Population projections for the whole country in 1978-2020 and by province in 1978-1990. Central Statistical Office. Statistical Survey 64, Helsinki 1979.

Ruotsinkielisen väestön kehitys Helsingissä, väestö 1.1.1972-1979 sekä ennusteet 1.1.1981 ja 1.1.1986 (The development of the Swedish speaking population in Helsinki, the population January 1, 1972-1979 and the prognosis January 1981 and January 1, 1986). Helsingin kaupungin tilastokeskus (The City of Helsinki, Statistical Office). Tilastoja A: $1980: 2,13 \mathrm{p}$.

Väestönmuutokset Helsingissä vuosina 1961-1975 (Population changes in Helsinki in 1961-1975). Helsingin kaupungin tilastokeskus (The City of Helsinki, Statistical Office). Tilastoja 1979 A 3. $98 \mathrm{p}$.

Väestöennuste (Population projection). Eläkkeensaajien lukumääriä koskevat ennusteet 1980-2050 (Projections 19802050 on the number of pensioners) Social Insurance Institution 1980, $43 \mathrm{p}$.

\section{AUTHOR INDEX}

Alanen, Antti - B

Allardt, E. - B

Aromaa, Arpo - J

Aura, Teuvo - B

Bingham, T. R. G. - K

Engman, Max - H1

Finnäs, Fjalar - F, N

Fougstedt, Gunnar - D

Haavio-Mannila, Elina - A, G, K

Hatunen, Hellevi - M

Herva, Aslak - A

Heikkilä, M - M

Hietala, Kari - H2

Hoem, Jan - E
Huuhtanen, Pekka - J
Hulkko, Jouko - D
Ilander, Kaija - M
Jutikkala, Eino - I
Järvenpää, Iiris - Q

Kandolin, $\mathrm{T}-\mathrm{K}$

Kaprio, J. - E

Kari, Kyllikki - A

Karjalainen, P. - J

Karjalainen, Y. - T, M

Kasanen, Viljo - M

Kaukiainen, Yrjö - I

Kemppainen, Eva-Kaisa - B, D

Keskimäki, Kaija - M

Kesäniemi, R. - E

Koivukangas, Olavi - H1

Kolari, Risto - E

Kortteinen, Timo - D

Koskenvuo, $\mathrm{M}-\mathrm{E}$

Kuikka, Ritva - M

Kulokari, Hannu - A, H1

Kuusilinna, Pirjo - B

Koskelo, Pauliine - G

Laaksonen, Seppo - D

Lähteinen, Martti - M

Lallukka, Seppo - D, M

Lehto, Markku - M

Lihr, S. - M

Lindgren, Jarl - F, G, K, M

Lindström, Kai - H1

Lönnqvist, J. - E

Majava, Altti - H1

Marin, R. - J, M

Marjanen, Matti - M

Markelin, Pasi - N

Markkanen, Erkki - B

Mattila, Rauno E. - F.

Mella, Ilkka - D

Miemois, K-J. - C

Moilanen, Kaisa-Liisa - B

Munther, Arja - P

Mäkelä, Anneli - H2

Niinivaara, R. - M

Niemi, Marja-Liisa - E

Nieminen, Mauri - D, H2, N, M

Notkola, Veijo - E

Nurmivaara, R. - M 
Ojala, Veijo - H2

Piironen, Pekka - B

Pitkänen, Kari - D, E, N, I

Pulkkinen, Aimo - E

Pöntinen, Seppo - H2

Rahunen, Aila - M

Rannikko, Pertti - C

Riihinen, Olavi - F

Rikkinen, K. - H1

Ritamies, Marketta - F

Rymalov, V. - A

Saarinen, Aino - G

Salo, Mikko - A, D, F, G, N

Sandlund, Tom - H1

Sarin, Mirja - H2

Sarna, S. - E

Sauli, Hannele - E
Saxen, Ake

Suominen, Leena - G

Suominen, Risto - M

Suviranta, Annikki - M

Söderling, Ismo - H1, H2

Tamasy, Josef - M

Tessieri, Enrique - H1

Tuisku, Terho - M

Tuomikoski, Hannu - N

Tuomisaari, T. - O

Uola, Mikko - H1

Uusitalo, H. - K

Valkonen, Tapani - D, E, H1

Vartiainen, Pertti - C, H2

Wiman, Ronald - D, H1

Virtanen, Keijo - H1

Visuri, Elina - M 